\title{
Image of Newton reopens historic divide
}

[LONDON] The unveiling last week of a 12feet-high, bronze statue of the seventeenth century physicist Sir Isaac Newton (right), outside the British Library's new building in central London, has renewed a debate over the significance of the painting by the eighteenth century poet and artist William Blake (below right), on which the design of the statue is based.

Sculptor Sir Eduardo Paolozzi says his statue is intended to show how art and science are interconnected. But at least one historian says the choice of subject is inappropriate, as Blake was highly critical of the English physicist.

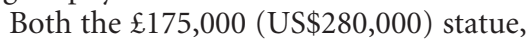
as well as Blake's original painting of Newton, show the physicist bending forward to plot or measure the Universe.

Simon Schaffer, reader in the history and philosophy of science at the University of Cambridge, says that this image was not designed to depict Newton in a flattering light. "Blake is associating Newton with an image of God as a tyrannical, and powerful measurer of the world. He is not celebrating Newton at all."

But Paolozzi, an honorary professor at the Royal College of Art in London, says: "If you see the original it shows that Blake made Newton into a God. He was extremely respectful of [Newton's] abilities." Paolozzi says that the imagery in the painting is at worst "a slight dig" at Newton.

Schaffer points out that Blake was among the first poets who attempted to understand

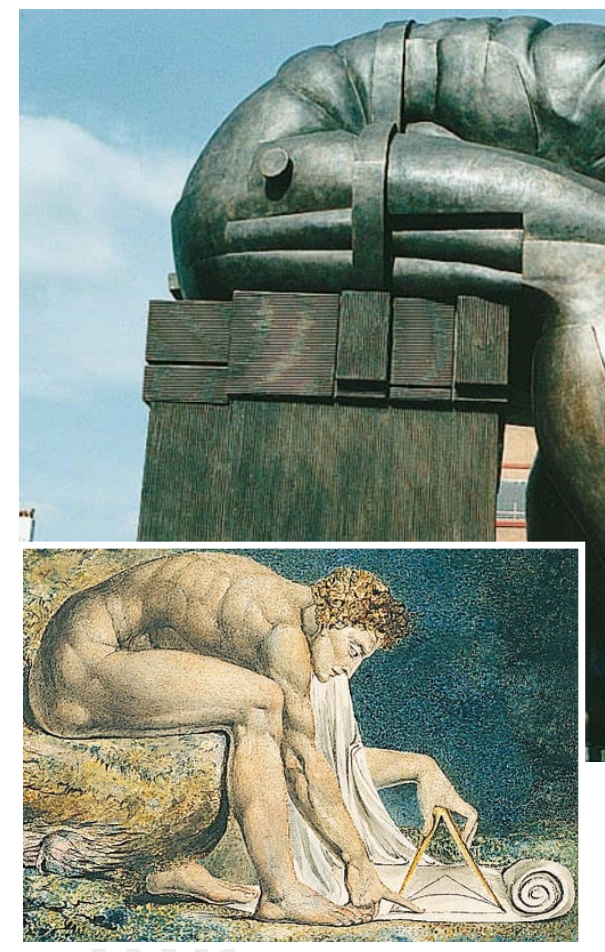

the implications of Newton's natural philosophy at a time when most contemporaries were happy merely to celebrate the triumph of reason. He says Blake disapproved of the view that science and reason were sufficient in themselves to explain the workings of the Universe, or those of life on Earth.

Blake, says Schaffer, was also critical of libraries, which he felt encouraged knowledge to be accumulated for display,

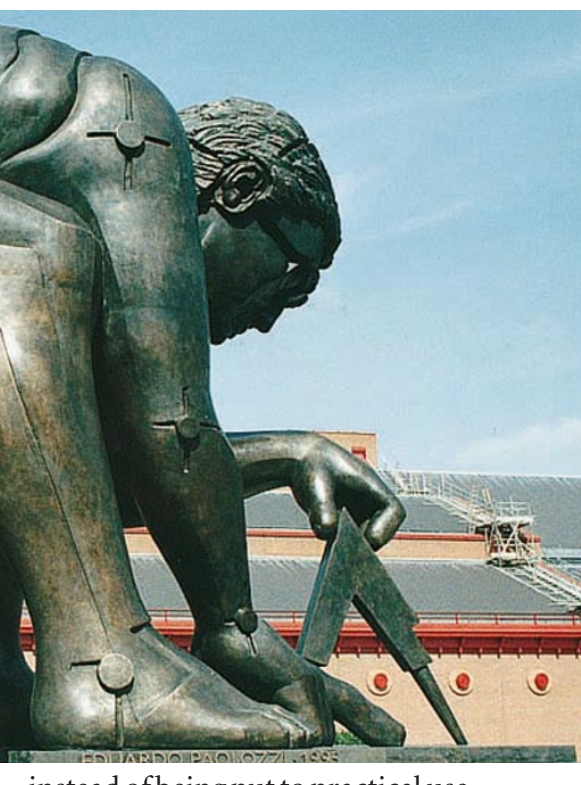

instead of being put to practical use.

But one leading art historian says the statue's concept is neither unusual nor inconsistent. It follows an established tradition in art in which the founders of mathematical sciences - Archimedes, Ptolemy, and Euclid — are shown measuring the world.

Ken Shirreffs, a spokesman for the British Library, says all those involved in the project are "aware of the ambiguities of Blake's views regarding Newton". But he adds that the statue has a much wider significance. "It is a fusion of art and science," and is an appropriate symbol for the British Library. The library opens in November. Ehsan Masood

\section{P. Snow's 'two cultures' thesis was just 'declinist whinging'}

[LEEDS, ENGLAND] Claims by the late British novelist C. P. Snow that a 'two cultures' gap separates those who have studied the humanities from those who have studied the sciences came under spirited attack last week from a historian of science for misrepresenting the central role science and technology have long played in British life.

"Snow is part of the problem, not the solution," David Edgerton of Imperial College, London, told the annual meeting of the British Association for the Advancement of Science in Leeds. He described Snow as an example of "declinist whinging" about British culture which remains "very popular among scientists and engineers".

Snow trained and worked as a physicist before the Second World War, later becoming a prominent novelist, a civil servant advising on scientific recruitment, and eventually a government minister.

His 'two cultures' thesis, presented in a lecture given in Cambridge in the late 1950s, remains widely quoted. Snow argued that
British culture, in contrast to that of its main economic competitors, had traditionally been 'anti-scientific' and opposed to technical progress. The lecture itself is still in print.

But, Edgerton points out, Snow "has no explanation for the rise of British science", nor for the 50-fold increase in the number of scientists in Britain between 1902 and 1966. "Snow is invoking an England without Charles Babbage, Michael Faraday, James Joule or Lord Kelvin,” he says. "Indeed without anything that could possibly explain that creation and rise of new universities with their strong emphasis on science and engineering, or the continued growth of British science-based industry."

Edgerton also criticizes Snow's international comparisons, suggesting that there is also reason to doubt his description of Britain's apparent weakness. "Britain may have been deficient in turning out graduates in science and engineering compared to the USA and the USSR, but not France,
Germany or Japan," he says.

Snow's characterization of the "two cultures' gap, built largely on the accepted fact that most senior politicians and civil servants came from humanities backgrounds - while many academics from such disciplines were often disparaging about their scientific colleagues - remains the starting point for much discussion about issues such as the future of Britain's education system.

But Edgerton complains that Snow's vision is based almost entirely on attitudes towards academic research physicists, while the views taken to represent British culture as a whole are predominantly those of British novelists.

"The fact that Snow has been taken seriously is a testimony to the importance of science in British culture," said Edgerton. "A modern justification for the [study of] the history of British science is not that Snow was right, but that he was profoundly wrong." 